\title{
Dietary patterns in the Belfast MONICA Project
}

\author{
BY ROSEMARY MCCLEAN, EVELYN MCCRUM, \\ GABRIEL SCALLY, DOROTHY MCMASTER, \\ CHRISTOPHER PATTERSON, NORMAN JACKSON \\ AND ALUN EVANS* \\ Department of Epidemiology and Public Health, Institute of Clinical Science, The Queen's \\ University of Belfast, Grosvenor Road, Belfast BT12 6BJ, Northern Ireland
}

Northern Ireland provides a centre for the World Health Organization co-ordinated MONICA Project (multinational monitoring of trends and determinants in cardiovascular disease; World Health Organization 1983). This is a 10-year study which aims to relate trends in incidence (mortality and morbidity) to changes in the levels of the major risk factors measured in three independent community surveys. The Belfast MONICA Project began in 1983 and will run until the end of 1992.

Apart from the local dimensions, adherence to a common protocol means that it will be possible to review, in parallel, the results from the thirty or so participating centres from around the world. Some countries are showing rapidly increasing incidence of ischaemic heart disease, whereas in others, such as North America and Australia the disease's mortality has almost halved over the past two decades.

The EURONUT Dietary Survey was one of a number of nutrition surveys carried out by the Belfast MONICA Project. Other studies include INTERSALT (a multi-centre comparison relating salt excretion to mean blood pressure in the population), CARDIAC (a Japanese study of salt and hypertension) and a study of the role of antioxidants in coronary heart disease.

In 1986, when the survey work described in the present report was carried out, Northern Ireland lay at the top of the world mortality league for ischaemic heart disease in males (Registrar General for Northern Ireland, 1987), and came second only to Scotland in females (Registrar General for Scotland, 1987).

Serum lipid levels are of crucial importance in atherogenesis and these in turn are related to dietary intake, a fact well established by pioneer studies such as the Seven Countries Study. Obviously, international comparisons of diet within the MONICA Project centres would have been of great interest, but unfortunately, because of the wide disparity in diets across the world it was considered impracticable to attempt to establish a uniform dietary surveillance system. However, an adequate assessment of dietary intake in the MONICA centres within Europe was obviously feasible. EURONUT, a concerted action project on nutrition in the European Community, deals with many aspects of population nutrition. A joint EURONUT/MONICA Project study was set up (Knuiman et al. 1985) to examine the dietary habits in the European populations with special regard to cardiovascular diseases.

As the study focused on the relationship between changes in diet and changes in coronary heart disease incidence with time, this could only realistically be carried out in middle-aged men as they alone would generate a sufficient number of events to allow

* For reprints. 
significance to be ascribed to any changes observed with time. The objective was to assess the extent to which trends in coronary heart disease morbidity and mortality were related to changes in dietary habits measured at the same time in defined communities in different countries. To be viable, it was considered that about fifteen centres within Europe should participate. It was proposed that independent dietary surveys should be carried out on two or three occasions. Longitudinal coronary heart disease incidence data would be available from the MONICA coronary event registration. The recommended dietary instrument was a $3 \mathrm{~d}$ food diary to be completed on 400 male participants (aged 45-64 years), with validation by means of $3 \mathrm{~d}$ weighed records kept by a $10 \%$ subsample. In Belfast it was decided that all participants should complete a $3 \mathrm{~d}$ weighed record.

\section{MATERIALS AND METHODS}

A random sample of 1067 males aged 45-64 years living within the MONICA study area was obtained from the Northern Ireland Central Services Agency General Practitioner list. All subjects were initially contacted by letter. To ensure a maximum response rate a predetermined procedure for tracing subjects was followed. This involved contacting the general practitioners and carrying out home visits in some cases. To encourage participation, sponsorship for a prize of a holiday was obtained from an airline and a local travel company. This was for a weekend for two in London; several subsidiary prizes were also awarded. The subjects who agreed to participate completed an introductory questionnaire verifying address, date of birth and clinic of choice. Nonresponse records were completed when possible.

Clinics were arranged in Health Centres and Clinics throughout the study area. Accompanying the appointment letter was a food frequency questionnaire modelled on the questionnaire developed by Yarnell et al. (1983). Subjects were asked to complete the questionnaire and bring it to the clinic.

The screening team consisted of a nurse, a nutritionist, a senior registrar in community medicine, a clerical worker, and laboratory technical staff to process blood samples. The clinic visit was conducted according to a strict protocol.

Background information was collected using an interviewer-administered screening record which included questions on past medical history, family history, current medication, smoking and drinking habits, exercise levels and social class. Each subject was also required to sign a consent form which complied with Ethical Committee recommendations.

Blood pressure was measured to diastolic phase $\mathrm{V}$ using a Hawkesley Random Zero Sphygomanometer. Measurement took place before venipuncture and after the subject had been seated for at least $5 \mathrm{~min}$. Height was measured to the nearest millimetre using a calibrated height ruler taped to a flat vertical surface. Electronic scales, the Seca 708 , were used to measure weight to the nearest $0.1 \mathrm{~kg}$. All subjects removed shoes and heavy outdoor clothing before measurement. Skinfold thicknesses were measured in triplicate at three sites (biceps, triceps and subscapular) using John Bull skinfold calipers.

A blood sample of $30 \mathrm{ml}$ was taken with the patient sitting and, as far as possible, without the use of a tourniquet. The use of a tourniquet was noted on the screening record. Centrifugation of blood and separation of serum was carried out within $3 \mathrm{~h}$ of venipuncture. Cholesterol was measured using the enzymic CHOD-PAP assay kit 
(Boehringer GmbH, Mannheim, West Germany). Phosphotungstic $\mathrm{Mg}^{2+}$ reagents were used for precipitation for high-density-lipoprotein (HDL)-cholesterol measurement. Cholesterol measurement was standardized through the World Health Organization Lipid Reference Centre in Prague.

The subject was interviewed regarding the food frequency questionnaire and any omissions made good. Instruction was then given on how to complete the $3 \mathrm{~d}$ weighed dietary record. Where possible, whoever was responsible for cooking the subject's meals (if not himself) was present. The session involved verbal instruction, practical demonstration and a practice run by the subject. Each subject was issued with written instructions, a diary, a contact telephone number and a set of electronic weighing scales. The scales used were the Dual Range Scale with a range of $2000 \mathrm{~g}$ in increments of $1 \mathrm{~g}$. Uneaten food was also weighed and recorded. Attendance at the clinic and, therefore, the start of the $3 \mathrm{~d}$ weighed dietary record was so arranged that each day of the week was adequately represented in the $3 \mathrm{~d}$ inventory.

A home visit was made by the nutritionist when the record was completed. The diary and scales were retrieved and the diary checked for any omissions of weights, cooking methods or brand names. Meals eaten away from home which went unweighed meant that caterers had to be visited to determine average portion weights and cooking methods.

The food diaries were coded using food composition tables (Paul \& Southgate, 1978; Paul et al. 1980). Food for which codes were not available were added using values from the literature (Wenlock et al. 1983; Broadhurst et al. 1987). The following measures were taken to extend the tables. Food manufacturers were contacted and asked to provide details of the composition of their foods; a laboratory technician was employed in the Agricultural and Food Sciences Faculty in the University to analyse certain foods which did not appear in the tables or where it was felt that the fatty acid content might vary from published values. The fatty acid content of foods with a fat content of a variable type, e.g. fried foods, was calculated using the method described by Fehily et al. (1984). The encoded diaries were analysed using a computer program acquired from the Dunn Nutrition Unit, Cambridge.

\section{RESULTS}

Screening for the EURONUT Project took place between September 1985 and September 1986. Of the 401 men who attended, 356 successfully kept a $3 \mathrm{~d}$ weighed dietary record. The total sample drawn was 1067 , of these 178 were ineligible, a further 114 were untraced after at least two visits to the last known address. There was a particular problem in mounting surveys in parts of Belfast where large tracts of housing were demolished. Response was very much better in more settled and rural areas. The overall response rate was $51.7 \%$. There were 374 non-responders and for these non-response records were completed on approximately one-third. Table 1 shows the mean nutrient intake in the 356 males aged 45-64 years. The mean energy intake was $9929 \mathrm{~kJ}(2368.7 \mathrm{kcal})$, protein $82.6 \mathrm{~g}$, total carbohydrate $272.5 \mathrm{~g}$, dietary fibre intake 20.4 $\mathrm{g}$ and total fat intake $100.3 \mathrm{~g}$, with saturated (S), monounsaturated and polyunsaturated (P) fatty acid intakes of $43.5,36.9$ and $12.5 \mathrm{~g}$ respectively. Linoleic acid accounted for $10 \cdot 1 \mathrm{~g}$. The P:S value was $0 \cdot 32$. Mean dietary cholesterol was $309 \cdot 1 \mathrm{mg}$ and the average alcohol intake $14.6 \mathrm{~g}$. 
Table 1. Mean daily nutrient intake of 356 males aged 45-64 years participating in the study

(Mean values and standard deviations)

\begin{tabular}{|c|c|c|c|c|}
\hline & \multicolumn{2}{|c|}{ Nutrient intake $(/ \mathrm{d})$} & \multicolumn{2}{|c|}{ Percentile } \\
\hline & Mean & SD & 5th & 95 th \\
\hline Energy: kcal & $2368 \cdot 7$ & $552 \cdot 7$ & $1494 \cdot 3$ & 3319.7 \\
\hline $\mathrm{kJ}$ & $9928 \cdot 8$ & 2314.7 & $6259 \cdot 3$ & $13913 \cdot 0$ \\
\hline Protein $(g)$ & $82 \cdot 6$ & $19 \cdot 5$ & $50 \cdot 6$ & $115 \cdot 6$ \\
\hline Total carbohydrate (g) & $272 \cdot 5$ & 75.6 & $153 \cdot 8$ & $405 \cdot 3$ \\
\hline Sugars $(\mathrm{g})$ & $103 \cdot 8$ & $47 \cdot 3$ & 37.9 & 188.9 \\
\hline Starches $(\mathrm{g})$ & $152 \cdot 0$ & $49 \cdot 3$ & 74.7 & $238 \cdot 3$ \\
\hline Dietary fibre (g) & $20 \cdot 4$ & $8 \cdot 4$ & $9 \cdot 2$ & $35 \cdot 3$ \\
\hline Total fat $(\mathrm{g})$ & $100 \cdot 3$ & $30 \cdot 7$ & $56 \cdot 4$ & $148 \cdot 1$ \\
\hline Saturated fatty acids $(S ; g)$ & $43 \cdot 5$ & $16 \cdot 5$ & $20 \cdot 6$ & $73 \cdot 0$ \\
\hline Monounsaturated fatty acids (g) & $36 \cdot 9$ & $17 \cdot 3$ & $17 \cdot 3$ & $67 \cdot 8$ \\
\hline Polyunsaturated fatty acids $(P ; g)$ & $12 \cdot 5$ & $7 \cdot 0$ & $4 \cdot 7$ & $27 \cdot 1$ \\
\hline Linoleic acid (g) & $10 \cdot 1$ & 6.5 & $3 \cdot 3$ & $23 \cdot 7$ \\
\hline$P: S$ & 0.32 & $0 \cdot 19$ & $0 \cdot 11$ & 0.72 \\
\hline Dietary cholesterol (mg) & $309 \cdot 1$ & $160 \cdot 8$ & $93 \cdot 0$ & $596 \cdot 7$ \\
\hline Alcohol (g) & $14 \cdot 6$ & $26 \cdot 5$ & 0.0 & $77 \cdot 5$ \\
\hline
\end{tabular}

Table 2. Mean daily nutrient intake of 356 males aged 45-64 years participating in the study

(Mean values and standard deviations)

\begin{tabular}{|c|c|c|c|c|}
\hline & \multicolumn{2}{|c|}{ Nutrient intake $(/ \mathrm{d})$} & \multicolumn{2}{|c|}{ Percentile } \\
\hline & Mean & SD & 5 th & 95th \\
\hline Sodium (mg) & $3187 \cdot 1$ & $946 \cdot 5$ & $1769 \cdot 9$ & $4784 \cdot 5$ \\
\hline Potassium (mg) & $3212 \cdot 4$ & 832.4 & $2010 \cdot 4$ & $4595 \cdot 2$ \\
\hline Calcium (mg) & $928 \cdot 6$ & $300 \cdot 3$ & $507 \cdot 8$ & $1469 \cdot 1$ \\
\hline Magnesium (mg) & $323 \cdot 9$ & 103.6 & $186 \cdot 2$ & $514 \cdot 5$ \\
\hline Iron (mg) & $13 \cdot 6$ & $5 \cdot 4$ & $7 \cdot 5$ & $24 \cdot 1$ \\
\hline Retinol $(\mu \mathrm{g})$ & $1029 \cdot 1$ & 2214.9 & $235 \cdot 0$ & $5361 \cdot 9$ \\
\hline Carotene $(\mu \mathrm{g})$ & $2056 \cdot 4$ & $2094 \cdot 0$ & $206 \cdot 2$ & 6377.4 \\
\hline Vitamin C (mg) & $59 \cdot 5$ & $47 \cdot 1$ & $17 \cdot 0$ & $128 \cdot 1$ \\
\hline
\end{tabular}

The mean nutrient intake for selected elements and vitamins is given in Table 2 . Potassium and sodium each amounted to just over $3 \mathrm{~g} / \mathrm{d}$, calcium just under $1 \mathrm{~g}$, magnesium about $0.3 \mathrm{~g}$ and iron $13.6 \mathrm{mg}$. The daily intake of retinol was just over $1 \mathrm{mg}$ and that of carotene slightly in excess of $2 \mathrm{mg}$; the mean daily intake of vitamin $\mathrm{C}$ was $59.5 \mathrm{mg}$. The mean percentage energy supplied by nutrients, including and excluding alcohol, is given in Table 3 . The percentage energy supplied from protein and carbohydrate including alcohol was 14.2 and 43.2 respectively, the corresponding values excluding alcohol were 14.9 and 44.4 . Total fat accounted for $38 \%$ including alcohol and $40.2 \%$ excluding alcohol. The respective percentages for saturated fatty acids were 16.5 and $17 \cdot 5$. Alcohol contributed $4 \%$ of total energy. 
Table 3. Mean percentage energy supplied by nutrients consumed by subjects participating in the study

\begin{tabular}{lcc}
\hline \hline & $\begin{array}{c}\text { Including } \\
\text { alcohol } \\
(\%)\end{array}$ & $\begin{array}{c}\text { Excluding } \\
\text { alcohol } \\
(\%)\end{array}$ \\
\hline Energy supplied from: & $14 \cdot 2$ & 14.9 \\
$\quad$ Protein & $43 \cdot 2$ & $44 \cdot 4$ \\
Carbohydrate & $38 \cdot 0$ & $40 \cdot 2$ \\
Total fat & 16.5 & $17 \cdot 5$ \\
Saturated fatty acids & $14 \cdot 0$ & 14.9 \\
Monounsaturated fatty acids & $4 \cdot 8$ & $5 \cdot 0$ \\
Polyunsaturated fatty acids & $4 \cdot 0$ & - \\
Alcohol & & \\
\hline \hline
\end{tabular}

Table 4. Serum lipid levels of males aged 45-54 and 55-64 years participating in the study (Mean values and standard deviations)

\begin{tabular}{|c|c|c|c|c|c|}
\hline \multirow{2}{*}{$\begin{array}{c}\text { Age } \\
\text { (years) }\end{array}$} & \multirow[b]{2}{*}{$n$} & \multirow[b]{2}{*}{ Mean } & \multirow[b]{2}{*}{ SD } & \multicolumn{2}{|c|}{ Pcrcentile } \\
\hline & & & & 5th & 95th \\
\hline \multicolumn{6}{|c|}{ Serum total cholesterol levels $(\mathrm{mmol} / \mathrm{l})^{*+}$} \\
\hline $45-54$ & 149 & $6 \cdot 19$ & 1.06 & $4 \cdot 35$ & 7.86 \\
\hline $55-64$ & 192 & $6 \cdot 12$ & 1.01 & $4 \cdot 62$ & 7.93 \\
\hline $45-64$ & 341 & $6 \cdot 15$ & 1.03 & 4.51 & $7 \cdot 90$ \\
\hline \multicolumn{6}{|c|}{ HDL-cholesterol levels $(\mathrm{mmol} / /)^{*}+$} \\
\hline $45-54$ & 148 & 1.22 & $0 \cdot 31$ & 0.77 & $1 \cdot 82$ \\
\hline $55-64$ & 188 & $1 \cdot 28$ & 0.37 & 0.79 & 1.93 \\
\hline $45-64$ & 336 & 1.26 & 0.35 & 0.78 & 1.92 \\
\hline
\end{tabular}

HDL, high-density lipoprotein.

* Conversion of SI to traditional units: $1 \mathrm{mmol} / \mathrm{l}=386 \mathrm{mg} / 1$ (approximately).

$\uparrow$ Missing values: 15 .

$\ddagger$ Missing values: 20 .

The results of lipid analysis are given in Table 4 . The mean cholesterol in 45-54-yearold males was $6.19 \mathrm{mmol} / \mathrm{l}$ and in the $55-64$ years age-group $6.12 \mathrm{mmol} / \mathrm{l}$. The corresponding HDL-cholesterol levels were 1.22 and $1.28 \mathrm{mmol} / \mathrm{l}$. In the $45-54$ years age-group $34 \cdot 2 \%$ were current smokers and $29 \%$ ex-smokers. In the older age-range only $24.9 \%$ were current smokers with $51.7 \%$ who were ex-smokers.

The systolic and diastolic blood pressures (Table 5) were $134 \mathrm{~mm} \mathrm{Hg}$ and $85 \mathrm{~mm} \mathrm{Hg}$ respectively in the younger age-group. Similarly, in the older age-group the mean levels were $142.9 \mathrm{~mm} \mathrm{Hg}$ and $84.2 \mathrm{~mm} \mathrm{Hg}$. Table 6 shows the distribution of body mass index. Just over half of all subjects were overweight; a further $12.3 \%$ of the younger group and $12.4 \%$ of the older group were obese: this meant that overall 63.3 and $64.1 \%$ of the respective age groups carried excess weight. 
Table 5. Systolic and diastolic blood pressure $(\mathrm{mm} \mathrm{Hg})$ of men aged 45-54 and 55-64 years participating in the study

(Mean values and standard deviations)

\begin{tabular}{|c|c|c|c|c|c|}
\hline \multirow[b]{2}{*}{$\begin{array}{c}\text { Age } \\
\text { (years) }\end{array}$} & \multirow[b]{2}{*}{$n$} & \multirow[b]{2}{*}{ Mean } & \multirow[b]{2}{*}{ SD } & \multicolumn{2}{|c|}{ Percentile } \\
\hline & & & & 5 th & 95 th \\
\hline \multicolumn{6}{|c|}{ Systolic blood pressure $(\mathrm{mm} \mathrm{Hg})^{*}$} \\
\hline $45-54$ & 155 & $134 \cdot 0$ & $17 \cdot 6$ & $108 \cdot 0$ & 166.6 \\
\hline $55-64$ & 200 & $142 \cdot 9$ & $22 \cdot 1$ & $110 \cdot 0$ & $181 \cdot 9$ \\
\hline $45-64$ & 355 & $139 \cdot 0$ & $20 \cdot 7$ & $109 \cdot 0$ & $176 \cdot 2$ \\
\hline \multicolumn{6}{|c|}{ Diastolic blood pressure $(\mathrm{mm} \mathrm{Hg})^{*}$} \\
\hline $45-54$ & 155 & $85 \cdot 0$ & $10 \cdot 0$ & $71 \cdot 0$ & $106 \cdot 1$ \\
\hline $55-64$ & 200 & $84 \cdot 2$ & $11 \cdot 9$ & $65 \cdot 0$ & $105 \cdot 0$ \\
\hline $45-64$ & 355 & $84 \cdot 6$ & $11 \cdot 1$ & $66 \cdot 8$ & $105 \cdot 2$ \\
\hline
\end{tabular}

* Missing values: 1 .

Table 6. Distribution of body mass index $\left(B M I ; \mathrm{kg} / \mathrm{m}^{2}\right)^{*}$ in men aged 45-54 and 55-64 years participating in the study

\begin{tabular}{ccccc}
\hline $\begin{array}{c}\text { Age } \\
\text { (years) }\end{array}$ & $n$ & $\begin{array}{c}\text { Overweight } \\
(\%)\end{array}$ & $\begin{array}{c}\text { Obese } \\
(\%)\end{array}$ & $\begin{array}{c}\text { Excess Weight } \\
(\%)\end{array}$ \\
\hline $45-54$ & 155 & $51 \cdot 0$ & $612 \cdot 3$ & $63 \cdot 3$ \\
$55-64$ & 201 & $51 \cdot 7$ & $12 \cdot 4$ & $64 \cdot 1$ \\
$45-64$ & 356 & $51 \cdot 4$ & $12 \cdot 4$ & $63 \cdot 8$ \\
\hline
\end{tabular}

* Overweight, BMI $>25$ and $\leqslant 30 \mathrm{~kg} / \mathrm{m}^{2}$; obese, BMI $>30 \mathrm{~kg} / \mathrm{m}^{2}$; excess weight, $\mathrm{BMI}>25 \mathrm{~kg} / \mathrm{m}^{2}$.

\section{DISCUSSION}

The study employed $3 \mathrm{~d}$ weighed food records starting on days dispersed throughout the week so that individual days were adequately represented and this system worked well. The objective was to assess mean levels of dietary intake rather than to characterize individual diets which may require the keeping of more lengthy records. The $3 \mathrm{~d}$ approach, moreover, should have reduced the problem of reactivity where individuals learn that certain foods are irksome to weigh and, therefore, modify their diets.

The overall response rate of $51.7 \%$ was disappointing, particularly in view of the fact that only 356 of the records could be analysed. The response rate achieved was low despite the fact that inducement in the form of a prize was offered to participants. Response was notably poorer in the parts of Belfast which have experienced the worst civil upheaval and generally was satisfactory in the settled areas around the city of Belfast. Response was especially poor in the younger age-group.

The problems about comparing results from the dietary survey is that surveys seldom use the same age-ranges. The EURONUT/MONICA age range of 45-64 years, in two equal age-bands, was chosen as representing that group of middle-aged males who were most likely to produce incident cases of myocardial infarction. In this way trends in 
dietary intake measured on different occasions over a decade could be examined against trends in incidence over the same period in many centres in Europe. The samples were sufficiently large to allow estimates of variation to be made and, therefore, significance could be confidently ascribed to any changes found over time. The mean energy intake was $9.93 \mathrm{MJ}$ in the present study compared to $9.86 \mathrm{MJ}$ in Cambridgeshire males aged 40-59 years (Bingham et al. 1981). Fat consumption in Cambridgeshire and Belfast was 102.3 and $100.3 \mathrm{~g}$ respectively; the mean dietary fibre intakes, just over $20 \mathrm{~g}$, were almost identical. In an Edinburgh study (Thomson et al. 1988), of 164 men aged 45-54 years (1982 means), total energy was $10.9 \mathrm{MJ}$, protein $91 \mathrm{~g}$ and fat $115 \mathrm{~g}$. Fibre amounted to $21.3 \mathrm{~g}$ and the P:S ratio of 0.34 was nearly identical to that in the present study $(0.32)$. In South Wales, Fehily et al. (1984) studied 493 40-59-year-old males. The mean energy intake was $10090 \mathrm{~kJ}(2412 \mathrm{kcal})$, fat $99.9 \mathrm{~g}$, protein $82.7 \mathrm{~g}$ and the $\mathrm{P}: S$ ratio 0.28 . Barker et al. (1988) in Northern Ireland found that in males in the 50-64 years age-range ( $n 38$ ), the total energy was $9800 \mathrm{~kJ}(2343 \mathrm{kcal}$ ) (protein $84.4 \mathrm{~g}$ and fat $102.3 \mathrm{~g}$ ); the mean energy supplied by total fat was $38.9 \%$, carbohydrate $43.4 \%$ and alcohol $1.7 \%$. In Belfast the respective percentages were $38 \cdot 0,43 \cdot 2$ and $4 \cdot 0$. Turning to vitamin $C$, in the $40-59$-yearold males in Cambridgeshire the average ascorbic acid consumption was $72.2 \mathrm{mg}$ as opposed to $59.5 \mathrm{mg}$ in the present study. Fe consumption was $13.6 \mathrm{mg}$ in the present study compared to $13.8 \mathrm{mg}$ reported by Barker et al. (1988), $12.7 \mathrm{mg}$ reported by Fehily et al. (1984) and $14.1 \mathrm{mg}$ reported by Bingham et al. (1981). In thirty 35-44-year-old males in Kilkenny, Ireland, Gibney et al. (1987) found a daily energy intake of $12.5 \mathrm{MJ}$, fibre $24.1 \mathrm{~g}$ and a respective distribution of percentage energy between protein, carbohydrate, fat and alcohol of $14.7,43 \cdot 3,36 \cdot 0$ and 5.9.

The mean levels of food energy and nutrients satisfy current recommended daily allowances (Department of Health and Social Security, 1979), although some of the subjects (5th percentile) were low in terms of energy, Fe and vitamin $\mathrm{C}$.

It is clear from the foregoing that the levels of nutrient and, in particular, fat intake do not differ appreciably from other parts of the British Isles and do not clearly explain the Province's poor heart disease mortality record. Nevertheless, to comply with COMA recommendations (Department of Heaith and Social Security, 1984) on diet and cardiovascular disease (which excluded alcohol) in Belfast in middle-aged males, the fat consumption would have to drop from 40.2 to $35 \%$ of total energy and saturated fat would require to fall from 17.5 to $15 \%$. The P:S ratio of 0.32 is lower than the recommendation of 0.45 . However, dietary fibre intake is inadequate according to the National Advisory Committee on Nutrition Education (NACNE) Working Party (1983) proposals, which recommends $30 \mathrm{~g} / \mathrm{d}$.

By comparison the changes required in the Belfast diet to meet current dietary guidelines for healthy American adults are substantial. The Nutrition Committee of the American Heart Association (1988), in line with World Health Organization (1982) guidelines, recommended a total fat intake of $30 \%$ of total energy. This would require reduction in Belfast of at least $21 \%$ total fat and in saturated fat by at least $39.4 \%$ (to achieve a level of $10 \%$ of energy). Polyunsaturated fat would need to increase by a maximum of $108 \%$. Carbohydrate intake also would have to increase by $27 \%$. The Belfast dietary cholesterol intake is about right.

The serum cholesterol levels are high with $82.4 \%$ in excess of the internationally accepted dèsirable level of $5.2 \mathrm{mmol} / \mathrm{l}$; with almost half $(46.3 \%)$ above $6.2 \mathrm{mmol} / \mathrm{l}$ which the Americans now consider to place adults at increased risk. These levels were almost 
identical to those found in larger MONICA population surveys (Evans et al. 1989), and systolic and diastolic blood pressures were almost identical to those found in the larger-scale surveys, apart from systolic blood pressure in the older age-group which was $2.6 \mathrm{~mm} \mathrm{Hg}$ lower in the present survey. The similarity of risk profiles between the present study and the main surveys gives reassurance that the sample was still representative of the population despite the poorer response rate. Almost two-thirds of males carried excess weight and this compares unfavourably with that reported from England and Wales (Knight, 1984).

In conclusion, the patterns of dietary intake found in the Belfast MONICA Project EURONUT dietary substudy were similar to those reported in other parts of the British Isles and do not adequately explain Northern Ireland's position at the top of the world ischaemic heart mortality league. There is, however, considerable room for improvement according to recent dietary guidelines emanating from various sources. A sizeable proportion of the population in this age-range is at increased risk in terms of cigarette smoking, serum cholesterol $>5.2 \mathrm{mmol} / \mathrm{l}$ and blood pressure $>140 / 90 \mathrm{~mm} \mathrm{Hg}$ (or on treatment). A total of $89 \%$ have at least one risk factor present.

The methodology for the $3 \mathrm{~d}$ weighed dietary record study is established in a sufficiently large sample so that changes can be reliably detected when the study is repeated in due course.

\section{REFERENCES}

Barker, M. E., McLean, S. I., McKenna, P. G., Reid, N. G., Strain, J. J., Thompson. K. A., Williamson, A. P. \& Wright, M. E. (1988). Diet, Lifestyle and Health in Northern Ireland: a report to the Health Promotion Research Trust. Coleraine. Northern Ireland: Centre for Applied Health Studies, University of Ulster.

Bingham, S., McNeil, N. I. \& Cummings, J. H. (1981). The diet of individuals: A study of a randomly-chosen cross section of British adults in a Cambridgeshire village. British Journal of Nutrition 45, 23-35.

Broadhurst, A. J., Wharf, S. G. \& Stockley, L. (1987). Fatty acid composition of selected foods consumed in a mixed diet study. Human Nutrition: Applied Nutrition 41A, 96-100.

Department of Health and Social Security (1979). Recommended Daily Amounts of Food Energy and Nutrients for Groups of People in the United Kingdom. Report on Health and Social Subjects no. 15. London: H.M. Stationery Office.

Department of Health and Social Security (1984). Diet and Cardiovascular Disease. Committee on Medical Aspects of Food Policy. Report of the Panel on Diet in Relation to Cardiovascular Disease. London: H.M. Stationery Office.

Evans, A. E., Kerr, M. McF., McCrum, E. E., McMaster, D., McCartney, L. K., Mallaghan, M. \& Patterson. C. C. (1989). Coronary risk factor prevalence in a high incidence area: results from the Belfast MONICA Project. Ulster Medical Journal 58, 60-68.

Fehily, A., Phillips, K. M. \& Sweetman, P. M. (1984). A weighed dietary survey of men in Caerphilly, South Wales. Human Nutrition: Applied Nutrition 40A, 419-425.

Gibney, M. J., Maloney, M. \& Shelly, E. (1987). The Kilkenny Health Project: patterns of food intake in individuals consuming low-, moderate- and high-fat diets. Proceedings of the Nutrition Society 46, 14A.

Knight. I. (1984). Heights and Weights of Adults in Great Britain. London H.M. Stationery Office.

Knuiman, J. T., Pietinen, P., De Backer, G. \& Ducimetiere, E. P. (1985). The MONICA-Project: Optional Study on the Surveillance of Dietary Intake of the Population With Regard to Cardiovascular Diseases Manual of Operations. EURONUT Report 6. The Netherlands: EURONUT.

National Advisory Committee on Nutrition Education (1983). A Discussion Paper on Proposals for Guidelines for Health Education in Britain. London: Health Education Council.

Nutrition Committee of the American Heart Association (1988). Dietary guidelines for healthy American adults. Circulation 77, 721a-724a.

Paul, A. A. \& Southgate, D. A. T. (1978). McCance and Widdowson's, The Composition of Foods, 4th ed. London: H.M. Stationery Office. 
Paul, A. A., Southgate, D. A. T. \& Russell, J. (1980). First Supplement to McCance and Widdowson's, The Composition of Foods. London: H.M. Stationery Office.

Registrar General for Northern Ireland (1987). Registrar General for Northern Ireland Report 1986. Belfast: H.M. Stationery Office.

Registrar General for Scotland (1987). Registrar General for Scotland Report 1986. Edinburgh: H.M. Stationery Office.

Thomson, M., Elton, R. A., Fulton, M., Brown, S., Wood, D. A. \& Oliver, M. F. (1988). Individual variation in the dietary intake in a group of Scottish men. Journal of Human Nutrition and Dietetics 1, 47-57.

Wenlock, R. W., Civil, L. M., King, R. T., Scuffam, D. \& Wiggins, R. A. (1983). The nutritional composition of British bread - a nationwide study. Journal of Science of Food and Agriculture 34, 1302-1318.

World Health Organization (1982). Prevention of coronary heart disease. Technical Report Series no. 678. Geneva: WHO.

World Health Organization (1983). Proposals for the Multinational Monitoring of Trends and Determinants in Cardiovascular Disease and Protocol (MONICA Project). Geneva: WHO.

Yarnell, J. W. G., Fehily, A. M., Milbank, J. E., Sweetman, P. M. \& Walker, C. L. (1983). Short dietary questionnaire for use in an epidemiological survey: comparison with weighed dietary records. Human Nutrition: Applied Nutrition 37A, 103-112. 